\title{
Effect of substitution of titanium by magnesium and niobium on structure and piezoelectric properties in $\left(\mathrm{Bi}_{1 / 2} \mathrm{Na}_{1 / 2}\right) \mathrm{TiO}_{3}$ ceramics
}

\author{
ZHOU CHANG-RONG*, LIU XIN-YU, LI WEI-ZHOU ${ }^{\dagger}$ and YUAN CHANG-LAI \\ Department of Information Material Science and Engineering, Guilin University of Electronic Technology, \\ Guilin, Guangxi 541004, P.R. China \\ ${ }^{\dagger}$ School of Materials Science and Engineering, Guangxi University, Nanning, Guangxi 530004, P.R. China
}

MS received 8 November 2007; revised 20 October 2008

\begin{abstract}
To develop new $\left(\mathrm{Bi}_{1 / 2} \mathrm{Na}_{1 / 2}\right) \mathrm{TiO}_{3}$-based ceramics with excellent piezoelectric properties, the similarities and the differences between PZT and $\left(\mathrm{Bi}_{1 / 2} \mathrm{Na}_{1 / 2}\right) \mathrm{TiO}_{3}$ ceramics were analysed. Based on the analysis, a new $\left(\mathrm{Bi}_{1 / 2} \mathrm{Na}_{1 / 2}\right) \mathrm{TiO}_{3}$-based piezoelectric ceramic of $\mathrm{B}$-site substitution of complex ions $\left(\mathrm{Mg}_{1 / 3} \mathrm{Nb}_{2 / 3}\right)^{4+}$ for $\mathrm{Ti}^{4+}$ was prepared by a conventional ceramic technique, and effect of complex ions $\left(\mathrm{Mg}_{1 / 3} \mathrm{Nb}_{2 / 3}\right)^{4+}$ addition on the microstructure, dielectric and piezoelectric properties was investigated. The results show that all compositions are mono-perovskite phase and the grain size increases with increasing content of $\left(\mathrm{Mg}_{1 / 3} \mathrm{Nb}_{2 / 3}\right)^{4+}$. The piezoelectric constant, $d_{33}$, first increases and then decreases, and electromechanical coupling factor, $k_{\mathrm{p}}$, varies insignificantly with increasing content of $\left(\mathrm{Mg}_{1 / 3} \mathrm{Nb}_{2 / 3}\right)^{4+}$.
\end{abstract}

Keywords. Lead-free piezoelectric ceramics; perovskite structure; substitution.

\section{Introduction}

$\mathrm{Pb}(\mathrm{Zr}, \mathrm{Ti}) \mathrm{O}_{3}(\mathrm{PZT})$ and related compositions have been the mainstay for high performance actuators and transducers, owing to their superior dielectric, piezoelectric and electromechanical coupling coefficients (Jaffe et al 1971). In the past, innovations in actuators and ultrasonic transducers have been the driving force for new developments in piezoelectric ceramics (Xiao et al 2006). Currently, the driving force is the result of environmental regulations. Therefore, it is necessary to develop environment-friendly lead-free piezoelectric ceramics to replace PZT based ceramics.

Among the lead-free compounds, bismuth sodium titanate $\left(\left(\mathrm{Bi}_{1 / 2} \mathrm{Na}_{1 / 2}\right) \mathrm{TiO}_{3}\right.$, abbreviated as $\left.\mathrm{BNT}\right)$ with $\mathrm{ABO}_{3}$ type perovskite structure has been considered to be a promising candidate for lead-free piezoelectric materials as BNT shows a strong ferroelectricity $\left(P_{\mathrm{r}}=38 \mu \mathrm{C} / \mathrm{cm}^{2}\right)$ and high Curie temperature $\left(T_{\mathrm{c}}=320^{\circ} \mathrm{C}\right.$ ) (Smolenski et al 1961). However, this ceramic has drawbacks such as high conductivity and large coercive field $\left(E_{\mathrm{c}}=73 \mathrm{kV} / \mathrm{cm}\right)$, which cause problems in poling process. As a result of these, a lot of work to modify and improve piezoelectric properties of BNT ceramics has been done by substitution of $\mathrm{BaTiO}_{3}$ (Takenaka et al 1991), $\left(\mathrm{Bi}_{1 / 2} \mathrm{~K}_{1 / 2}\right) \mathrm{TiO}_{3}$ (Sasaki et al 1999), $\mathrm{NaNbO}_{3}$ (Li et al 2004), $\mathrm{BiFeO}_{3}$ (Nagata et al 1999a), $\mathrm{Ba}\left(\mathrm{Cu}_{1 / 2} \mathrm{~W}_{1 / 2}\right) \mathrm{O}_{3}$ (Elkechai et al 1996), $\mathrm{PbTiO}_{3}$

\footnotetext{
*Author for correspondence (zcr750320@yahoo.com.cn)
}

(Kuharuangrong and Schulze 1996), and so on. Based on the binary BNT system, some ternary systems with good piezoelectric properties such as $\left(\mathrm{Bi}_{1 / 2} \mathrm{Na}_{1 / 2}\right) \mathrm{TiO}_{3}-\left(\mathrm{Bi}_{1 / 2} \mathrm{~K}_{1 / 2}\right)$ $\mathrm{TiO}_{3}-\mathrm{BaTiO}_{3}$ (Chen and $\mathrm{Lu}$ 2007), $\left(\mathrm{Bi}_{1 / 2} \mathrm{Na}_{1 / 2}\right) \mathrm{TiO}_{3}-$ $\left(\mathrm{Bi}_{1 / 2} \mathrm{~K}_{1 / 2}\right) \mathrm{TiO}_{3}-\mathrm{NaNbO}_{3}$ (Li et al 2005a), $\left(\mathrm{Bi}_{1 / 2} \mathrm{Na}_{1 / 2}\right)$ $\mathrm{TiO}_{3}-\left(\mathrm{Bi}_{1 / 2} \mathrm{~K}_{1 / 2}\right) \mathrm{TiO}_{3}-\mathrm{KNbO}_{3}$ (Li et al $\left.2005 \mathrm{~b}\right),\left(\mathrm{Bi}_{1 / 2} \mathrm{Na}_{1 / 2}\right)$ $\mathrm{TiO}_{3}-\mathrm{BaTiO}_{3}-\mathrm{BiFO}_{3}$ (Nagata et al 1999b) were also studied. However, the piezoelectric properties of these ceramics are not high enough for most practical uses.

In order to further enhance the properties of BNT ceramics and meet the requirements for practical uses, it is necessary to develop new BNT-based ceramics. To develop new BNT-based ceramics, the similarities and the differences between BNT ceramics and PZT ceramics were analysed. Firstly, compared with BNT-based ceramics, the high piezoelectric properties are attributed to $\mathrm{Pb}$ because the $\mathrm{Pb} 6 \mathrm{~s}$ and $\mathrm{O} 2 p$ state are strongly hybridized in PZT ceramics (Cohen and Krakauer 1992). Then, bismuth lies next to lead in the periodic table, its atomic weight is as large as that of lead and the electronic configuration of $\mathrm{Bi}^{3+}$ is identical to that of $\mathrm{Pb}^{2+}$. Therefore, it is assumed that the large ferroelectricity of BNT-based solid solutions is attributed to $\left(\mathrm{Bi}_{1 / 2} \mathrm{Na}_{1 / 5}\right)^{2+}$ ions, especially $\mathrm{Bi}^{3+}$ ions, in the $\mathrm{A}$ sites of $\mathrm{ABO}_{3}$ perovskite structure (Nagata and Takenaka 1997). Besides, in PZT-based ceramics, the $\mathrm{Pb}\left(\mathrm{Mg}_{1 / 3} \mathrm{Nb}_{2 / 3}\right) \mathrm{O}_{3}-\mathrm{PbTiO}_{3}$ ceramics with $\mathrm{B}$ site substitution of complex ions of $\left(\mathrm{Mg}_{1 / 3} \mathrm{Nb}_{2 / 3}\right)^{4+}$ have excellent piezoelectric properties (Chen et al 2000). Based on the above discussion, it is assumed that the B-site substitution of complex ions of $\left(\mathrm{Mg}_{1 / 3} \mathrm{Nb}_{2 / 3}\right)^{4+}$ for 
$\mathrm{Ti}^{4+}$ in BNT ceramics should have excellent piezoelectric properties. Therefore, the lead-free ceramics of $\left(\mathrm{Bi}_{1 / 2}\right.$ $\left.\mathrm{Na}_{1 / 2}\right) \mathrm{Ti}_{1-x}\left(\mathrm{Mg}_{1 / 3} \mathrm{Nb}_{2 / 3}\right)_{x} \mathrm{O}_{3}$ have been prepared and the effect of complex ions substitution of $\left(\mathrm{Mg}_{1 / 3} \mathrm{Nb}_{2 / 3}\right)^{4+}$ for $\mathrm{Ti}^{4+}$ in the B-sites for $\left(\mathrm{Bi}_{1 / 2} \mathrm{Na}_{1 / 2}\right) \mathrm{TiO}_{3}$ perovskite lattice on structure and piezoelectric properties was investigated.

\section{Experimental}

High purity $\mathrm{Bi}_{2} \mathrm{O}_{3}, \mathrm{Na}_{2} \mathrm{CO}_{3}, \mathrm{TiO}_{2}, \mathrm{MgCO}_{3}$ and $\mathrm{Nb}_{2} \mathrm{O}_{5}$ (purity over $99.5 \%$ ) powders were used as starting materials. Our preliminary experiments found that $\left(\mathrm{Bi}_{1 / 2} \mathrm{Na}_{1 / 2}\right)$ $\mathrm{Ti}_{1-x}\left(\mathrm{Mg}_{1 / 3} \mathrm{Nb}_{2 / 3}\right)_{x} \mathrm{O}_{3}$ ceramics were not well synthesized by mixing and calcinating all these above powders as used in the conventional oxide mixing process. Therefore, the $\left(\mathrm{Bi}_{1 / 2} \mathrm{Na}_{1 / 2}\right) \mathrm{Ti}_{1-x}\left(\mathrm{Mg}_{1 / 3} \mathrm{Nb}_{2 / 3}\right)_{x} \mathrm{O}_{3}$ ceramics were prepared by using a modified two-step calcination approach, in which $\mathrm{MgCO}_{3}$ and $\mathrm{Nb}_{2} \mathrm{O}_{5}$ powders were first calcinated at $1100^{\circ} \mathrm{C}$ for $4 \mathrm{~h}$ to be compound of $\mathrm{MgNb}_{2} \mathrm{O}_{6}$, then $\mathrm{MgNb}_{2} \mathrm{O}_{6}$ was blended with other powders and calcined at $900^{\circ} \mathrm{C}$ for $2 \mathrm{~h}$. After calcinations, the mixture was ballmilled for $24 \mathrm{~h}$, dried and granulated with PVA as a binder. The granulated powders were pressed into discs with diameter $18 \mathrm{~mm}$ and thickness $1.2 \mathrm{~mm}$. The compacted discs were sintered at $1190^{\circ} \mathrm{C}$ for $2 \mathrm{~h}$ in air. Silver paste was fired on both faces of the discs at $650^{\circ} \mathrm{C}$ for $30 \mathrm{~min}$ as electrodes. The specimens for measurement of piezoelectric properties were poled in silicon oil at $80^{\circ} \mathrm{C}$ under $4 \sim 7 \mathrm{kV} / \mathrm{mm}$ for $15 \mathrm{~min}$. After $24 \mathrm{~h}$, piezoelectric properties were measured using an impedance analyser (Agilent 4294A) by the resonant and anti-resonant method. The microstructure of sintered samples was observed by a scanning electron microscope (JSM-5610LV), and crystal structure was measured by X-ray diffractometer (Bruker D8-Advance). Piezoelectric constant, $d_{33}$, was measured with a $d_{33}$ meter (China of Acoustics ZJ-3A).

\section{Results and discussion}

Figure 1 shows the X-ray diffraction (XRD) patterns of $\left(\mathrm{Bi}_{1 / 2} \mathrm{Na}_{1 / 2}\right) \mathrm{Ti}_{1-x}\left(\mathrm{Mg}_{1 / 3} \mathrm{Nb}_{2 / 3}\right)_{x} \mathrm{O}_{3}$ ceramics in the $2 \theta$ range of $20-80^{\circ}$. It is clear that all compositions exhibit typical $\mathrm{ABO}_{3}$ perovskite diffraction peaks, and no trace of secondary phases is detectable. The lattice parameter and angle parameter of $\left(\mathrm{Bi}_{1 / 2} \mathrm{Na}_{1 / 2}\right) \mathrm{Ti}_{1-x}\left(\mathrm{Mg}_{1 / 3} \mathrm{Nb}_{2 / 3}\right)_{x} \mathrm{O}_{3}$ ceramics are shown in table 1 . The lattice and angle parameters were indexed to be a rhombohedral symmetry structure, implying that $\left(\mathrm{Mg}_{1 / 3} \mathrm{Nb}_{2 / 3}\right)^{4+}$ ions dissolved into the BNT lattice and does not cause an obvious change in the phase structure. It can be seen that lattice dimensions of the $\left(\mathrm{Bi}_{1 / 2}\right.$ $\left.\mathrm{Na}_{1 / 2}\right) \mathrm{Ti}_{1-x}\left(\mathrm{Mg}_{1 / 3} \mathrm{Nb}_{2 / 3}\right)_{x} \mathrm{O}_{3}$ ceramics increase with the increasing content of $\left(\mathrm{Mg}_{1 / 3} \mathrm{Nb}_{2 / 3}\right)^{4+}$. According to Shannon's effective ionic radius with a coordination number of six (Shannon 1976), $\left(\mathrm{Mg}_{1 / 3} \mathrm{Nb}_{2 / 3}\right)^{4+}$ has an average radius of $0.67 \AA$, which is close to that of $\mathrm{Ti}^{4+}(0.61 \AA)$. There- fore, $\left(\mathrm{Mg}_{1 / 3} \mathrm{Nb}_{2 / 3}\right)^{4+}$ ionic should enter into the six-fold coordinated B site of the perovskite structure to substitute for $\mathrm{Ti}^{4+}$ because of radius matching, which leads to the increase of lattice dimensions.

Figure 2 shows typical microstructures of sintered $\left(\mathrm{Bi}_{1 / 2} \mathrm{Na}_{1 / 2}\right) \mathrm{Ti}_{1-x}\left(\mathrm{Mg}_{1 / 3} \mathrm{Nb}_{2 / 3}\right)_{x} \mathrm{O}_{3}$ ceramics. With the substituting content of $x$ increasing, the grain size increases, and then a high dense microstructure is obtained. Examination of the microstructure in the samples with high level substituting revealed the presence of needle-like grains throughout the samples. Similar microstructure containing needle-like grains has been reported by Nagata and Takenaka (2001) in Mn doped $\left(\mathrm{Bi}_{1 / 2} \mathrm{Na}_{1 / 2}\right) \mathrm{TiO}_{3}$. They attributed this phenomenon to the presence of nonstoichiometry due to the rejection of Bi by Mn. The formation of needle-shape phase may be attributed to the vacancies which were produced by vapourizing of $\mathrm{Bi}$ during the high temperature sintering process.

Figure 3 shows the piezoelectric constant, $d_{33}$ and the planar electromechanical coupling factor, $k_{\mathrm{p}}$, of $\left(\mathrm{Bi}_{1 / 2}\right.$ $\left.\mathrm{Na}_{1 / 2}\right) \mathrm{Ti}_{1-x}\left(\mathrm{Mg}_{1 / 3} \mathrm{Nb}_{2 / 3}\right)_{x} \mathrm{O}_{3}$ ceramics as a function of $x$. The piezoelectric constant, $d_{33}$, first increases sharply with $x$ increasing from 0.005 to 0.015 , and then decreases with $x$ further increasing with the maximum value of $105 \mathrm{pC} / \mathrm{N}$ at $x=0.015$. However, the planar electromechanical coupling factor, $k_{\mathrm{p}}$, has no evident change with increase of $x$.

Figure 4 shows the dielectric constant, $\varepsilon_{\mathrm{r}}$ and the dielectric loss, $\tan \delta$, at room temperature of the $\left(\mathrm{Bi}_{1 / 2} \mathrm{Na}_{1 / 2}\right)$ $\mathrm{Ti}_{1-x}\left(\mathrm{Mg}_{1 / 3} \mathrm{Nb}_{2 / 3}\right)_{x} \mathrm{O}_{3}$ ceramics as a function of $x$. The dielectric constant, $\varepsilon_{\mathrm{r}}$, increases with increasing $\left(\mathrm{Mg}_{1 / 3}\right.$ $\left.\mathrm{Nb}_{2 / 3}\right)^{4+}$ fraction up to $x=0.015$ with $\varepsilon_{\mathrm{r}}=435$ and then decreases. The dielectric loss $\tan \delta$ increases linearly with increasing $x$. Owing to the ion radius of $\left(\mathrm{Mg}_{2 / 3} \mathrm{Nb}_{1 / 3}\right)^{4+}$ which is larger than that of $\mathrm{Ti}^{4+},\left(\mathrm{Mg}_{2 / 3} \mathrm{Nb}_{1 / 3}\right)^{4+}$ substituting

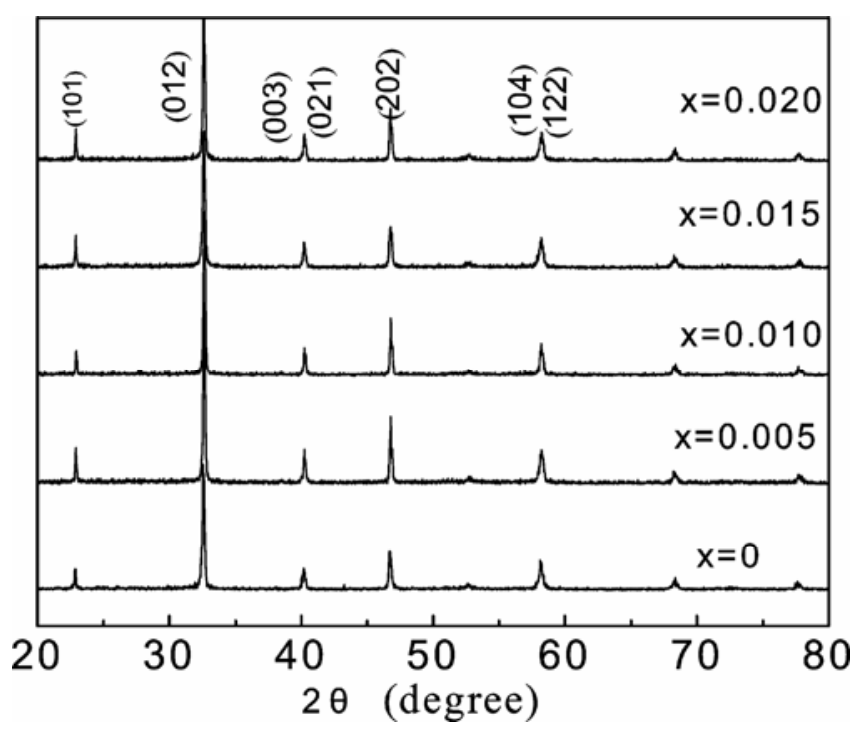

Figure 1. XRD patterns of $\left(\mathrm{Bi}_{1 / 2} \mathrm{Na}_{1 / 2}\right) \mathrm{Ti}_{1-x}\left(\mathrm{Mg}_{1 / 3} \mathrm{Nb}_{2 / 3}\right)_{x} \mathrm{O}_{3}$ ceramics. 


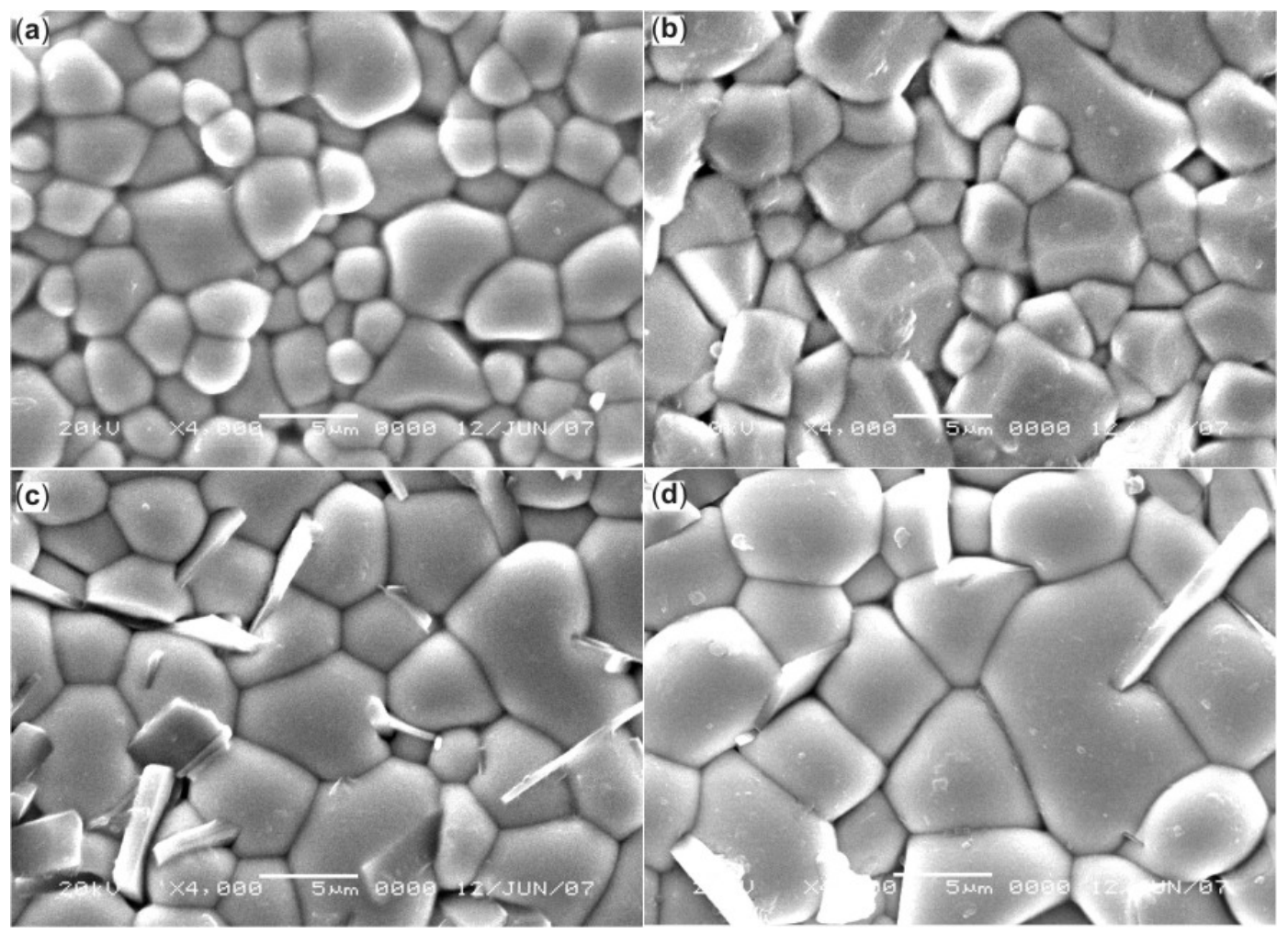

Figure 2. SEM micrographs of $\left(\mathrm{Bi}_{1 / 2} \mathrm{Na}_{1 / 2}\right) \mathrm{Ti}_{1-x}\left(\mathrm{Mg}_{1 / 3} \mathrm{Nb}_{2 / 3}\right)_{x} \mathrm{O}_{3}$ ceramics with (a) $x=0 \cdot 005$, (b) $x=$ $0.010,(\mathbf{c}) x=0.015$ and $(\mathbf{d}) x=0.020$.

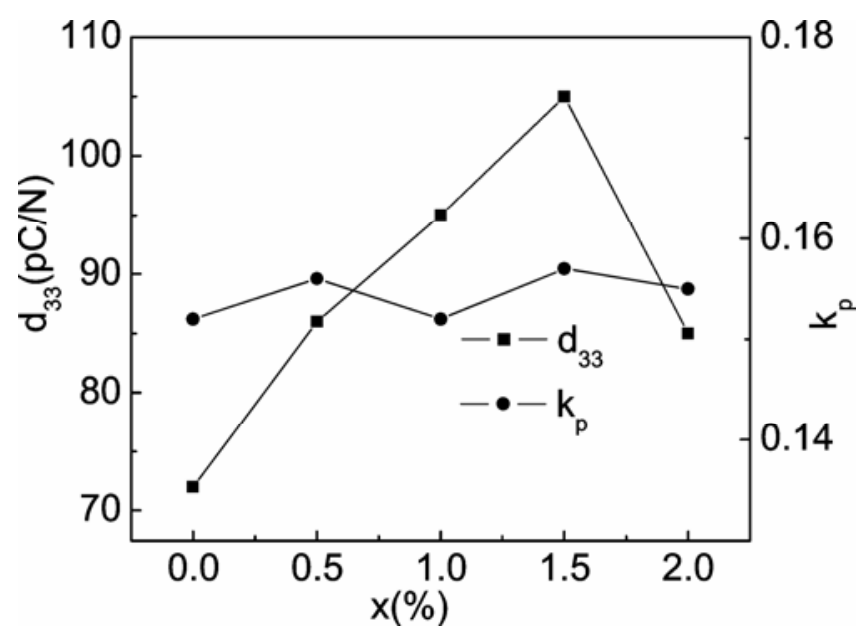

Figure 3. Piezoelectric constant, $d_{33}$ and planar electromechanical coupling factor, $k_{\mathrm{p}}$, of $\left(\mathrm{Bi}_{1 / 2} \mathrm{Na}_{1 / 2}\right) \mathrm{Ti}_{1-x}$ $\left(\mathrm{Mg}_{1 / 3} \mathrm{Nb}_{2 / 3}\right)_{x} \mathrm{O}_{3}$ ceramics as a function of $x$.

Table 1. The lattice parameter and angle parameter of $\left(\mathrm{Bi}_{1 / 2}\right.$ $\left.\mathrm{Na}_{1 / 2}\right) \mathrm{Ti}_{1-x}\left(\mathrm{Mg}_{1 / 3} \mathrm{Nb}_{2 / 3}\right)_{x} \mathrm{O}_{3}$ ceramics.

\begin{tabular}{lll}
\hline$x$ & $a(\mathrm{~nm})$ & $\alpha(0)$ \\
\hline 0 & 3.887 & 89.66 \\
0.005 & 3.892 & 89.63 \\
0.010 & 3.892 & 89.63 \\
0.015 & 3.895 & 89.60 \\
0.020 & 3.897 & 89.58 \\
\hline
\end{tabular}

$\mathrm{Ti}^{4+}$ leads to the lattice deformation. The lattice deformation facilitates the reorientation of ferroelectric domains and causes the increase in dielectric constant and dielectric loss. With further increasing content of $\left(\mathrm{Mg}_{2 / 3}\right.$ $\left.\mathrm{Nb}_{1 / 3}\right)^{3+}$, the decrease of dielectric constant may be the presence of the needle-shaped phase.

The above result is different from the assumption we concluded from the analysis between PZT and BNT ceramics. Many theories have been proposed to explain the piezoelectric properties change in the modified piezoelectric ceramics. Yamashita et al (2000) indicated that the electromechanical coupling factor $\left(k_{\mathrm{p}}\right)$ tended to increase with the mass difference between the perovskite A-site and B-site cations by studying the effects of the molecular mass of the B-site cations on $k_{\mathrm{p}}$ of lead-based perovskite piezoelectric materials. Yan et al (2005) exhibited that the comprehensive factor (containing the ionic size, atomic weight and electric negative) is related to the piezoelectric properties by studying the effects of the differences of the ionic size, atomic weight and electric negative of the $\mathrm{A}$-site and $\mathrm{B}$-site ions of $\mathrm{ABO}_{3}$ perovskite $\left(\mathrm{Bi}_{1 / 2}\right.$ $\left.\mathrm{Na}_{1 / 2}\right) \mathrm{TiO}_{3}$-based solid solutions. Wang et al (2005) showed that the change of random field by doping was a predominant factor affecting the dielectric and piezoelectric properties by studying the bismuth-containing complex perovskite. These indicate that the mechanism of the high piezoelectric activity is complex. The unexpected low piezoelectric properties of the B-site substituting BNT- 


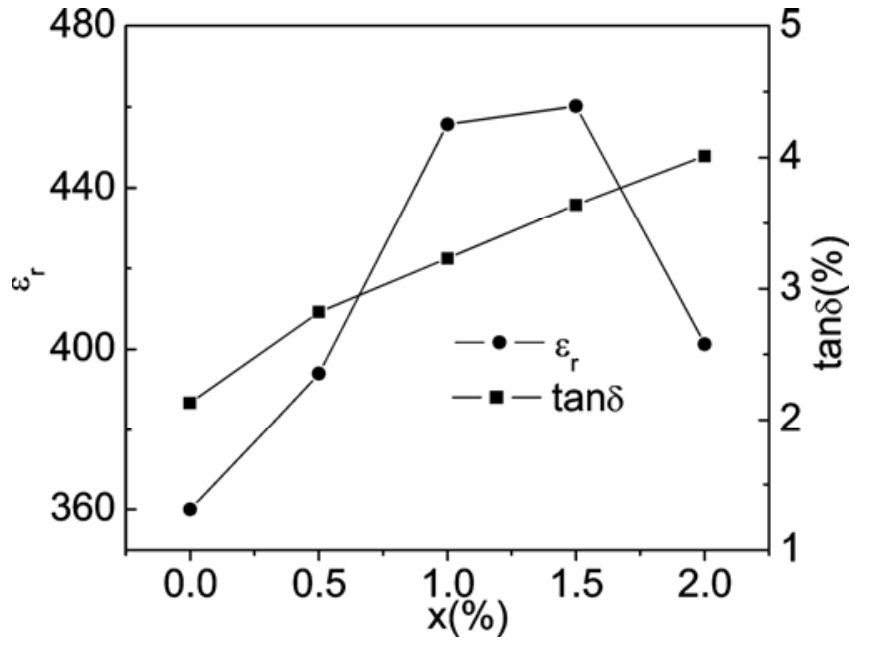

Figure 4. Dielectric constant, $\varepsilon_{\mathrm{r}}$ and dielectric loss $\tan \delta$ of $\left(\mathrm{Bi}_{1 / 2} \mathrm{Na}_{1 / 2}\right) \mathrm{Ti}_{1-x}\left(\mathrm{Mg}_{1 / 3} \mathrm{Nb}_{2 / 3}\right)_{x} \mathrm{O}_{3}$ ceramics as a function of $x$.

based ceramics may be attributed to the deference between the A-site complex ions of $\left(\mathrm{Bi}_{1 / 2} \mathrm{Na}_{1 / 2}\right)^{2+}$ in BNT ceramics and single ions of $\mathrm{Pb}^{2+}$ in PZT ceramics. Also, the morphotropic phase boundary(MPB) is an important factor and further study is in progress.

\section{Conclusions}

Lead-free piezoelectric ceramics of $\left(\mathrm{Bi}_{1 / 2} \mathrm{Na}_{1 / 2}\right) \mathrm{Ti}_{1-x}$ $\left(\mathrm{Mg}_{1 / 3} \mathrm{Nb}_{2 / 3}\right)_{x} \mathrm{O}_{3}$ with $x=0,0.005,0.015,0.020$ and 0.025 have been synthesized by a two-step calcination approach. The effect of cationic substitution of magnesium and niobium for titanium in the $\mathrm{B}$ sites for $\left(\mathrm{Bi}_{1 / 2} \mathrm{Na}_{1 / 2}\right) \mathrm{TiO}_{3}$ perovskite lattice on structure and piezoelectric properties were investigated. X-ray diffraction and SEM analysis show that the materials are mono-perovskite phase and grain size increases with increasing $x$. The piezoelectric constant, $d_{33}$, first increases and then decreases with increasing $x$, showing the maximum value of $105 \mathrm{pC} / \mathrm{N}$ at $x=0.015$. The planar electromechanical coupling factor, $k_{\mathrm{p}}$, has no evident change with increasing $x$. The results indicate that the mechanism of the high piezoelectric activity is complex and the low piezoelectric properties of the B-site substituting BNT-based ceramics may be due to the A-site complex ions of $\left(\mathrm{Bi}_{1 / 2} \mathrm{Na}_{1 / 2}\right)^{2+}$.

\section{References}

Chen Z W and Lu Z Y 2007 Key Eng. Mater. 336-338 54

Chen Y H, Hirose S and Viehland D 2000 Jpn J. Appl. Phys. Part 1394843

Cohen R E and Krakauer H 1992 Ferroelectrics 13665

Elkechai O, Manier M and Mercurio J P 1996 Phys. Status Solidi A Appl. Res. 157499

Jaffe B, Cook W and Jaffe H 1971 Piezoelectric ceramics (New York: Academic Press)

Kuharuangrong S and Schulze W A 1996 J. Am. Ceram. Soc. 79 1273

Li Y M, Chen W, Zhou J and Xu Q 2004 Mater. Sci. Eng. B112 5

Li Y M, Chen W, Xu Q and Zhou J 2005a J. Electroceram. 1453

Li Y M, Chen W, Xu Q and Zhou J 2005b Mater. Sci. 403625

Nagata H and Takenaka T 1997 Jpn J. Appl. Phys. Part 136 6055

Nagata H and Takenaka T 2001 J. Am. Ceram. Soc. 211299

Nagata H, Koizumi N and Takenaka T 1999a Key Eng. Mater. 169-170 37

Nagata H, Koizumi N, Kuroda N, Igarashi I and Takenaka T 1999 Ferroelectrics 229273

Sasaki A, Chiba T, Mamiya Y and Otsuki E 1999 Jpn. J. Appl. Phys. Part 1385564

Shannon R D 1976 Acta Crystallogr. A32 751

Smolenski G A, Isupv V A and Aganovskaya A I 1961 J. Sov. Phys. Solid State 2651

Takenaka T, Maruyama K and Sakata K 1991 Jap. J. Appl. Phys. 302236

Wang R, Shimojo Y, Sekiya T and Itoh M 2005 Solid State Commun. 134791

Xiao D Q, Lin D M, Zhu J G and Yu P J 2006 Electroceram. 16 271

Yamashita Y, Hosona Y, Harada K and Ichinose N 2000 Jpn. J. Appl. Phys. Part 1395593

Yan H J, Xiao D Q, Yu P, Zhu J G and Lin D M 2005 Mater. Design 26474 